\title{
Individual variation in the protein profile of the venom of Mesobuthus gibbosus (Brullé, 1832, Scorpiones: Buthidae) from Turkey
}

\author{
Ozkan O (1), Ciftci G (2)
}

(1) Refik Saydam Public Health Agency, Ankara, Turkey; (2) Department of Biochemistry, University of 19 May, Faculty of Veterinary Medicine, Samsun, Turkey.

\begin{abstract}
Mesobuthus gibbosus (Brullé, 1832) scorpions were collected from the Mugla province in the Aegean region of Turkey and housed in individual boxes. After extraction, the venom composition was analyzed using gel electrophoresis (SDS-PAGE). Interestingly, all scorpion venom samples contained only one protein band ( $\sim 68 \mathrm{kDa}$ ) in common. Two protein bands ( 30 and $98 \mathrm{kDa}$ ) were common in six venom samples and were absent in the other venoms. Furthermore, two different protein bands ( $28 \mathrm{and} 45 \mathrm{kDa}$ ) were detected in seven venom samples. This study proposes possible variations in the composition of individual scorpion venom samples collected from the same geographic region, based on the electrophoretic profile. Additional studies will be necessary in order to assess these variations further and to identify the proteins corresponding to the bands.
\end{abstract}

Key words: scorpion, Mesobuthus gibbosus, venom, protein, Turkey.

Scorpion envenomation still remains a major health problem in many tropical and subtropical countries (1). Antivenom is still widely used in the treatment of envenomation as there are no vaccines or other effective agents available against animal venoms (2). Venom pooling is extremely important in the production of viable antivenoms that can effectively treat scorpionism cases (3). However, milking procedure, climate of the region and season of collecting scorpions, all contribute to possible interspecies variation in the venom collected. (46). Moreover, the toxin composition, (e.g., protein content) and toxicity of the scorpion venom depend on multiple factors, including genus and species, geographic origin and age of the scorpion, its physiologic and feeding state, structure of the telson, and amount and composition of injected venom.

Mesobuthus gibbosus is considered a medically important species in the Aegean region, and in Central and East Anatolia, Turkey (7). Suzek et al. (8) report 262 patients stung by M. gibbosus scorpion in Mugla province between 1999 and 2001. Ozkan et al. (7) observed that the largest numbers of cases were reported in the summer and that the majority of scorpion stings (60\%) were observed in the Aegean, Central and East Anatolia regions of Turkey; and, more specifically, a larger number of cases were reported in the Mugla province than in the other provinces of the Aegean region.

M. gibbosus scorpions were collected from the same biotope during the summer period in the Mugla province. Analyses were performed with fresh venom, collected from the original habitats; specifically, the individual protein variation in the venom of M. gibbosus scorpion species was investigated using sodium dodecyl sulfate polyacrylamide gel electrophoresis (SDS-PAGE) (9).

Specimens (eight males and three females) were collected in the same period (August) and from the same habitat, the Mugla province. Animals were identified as M. gibbosus under stereomicroscope and housed in individual plastic boxes. Size-compatible 


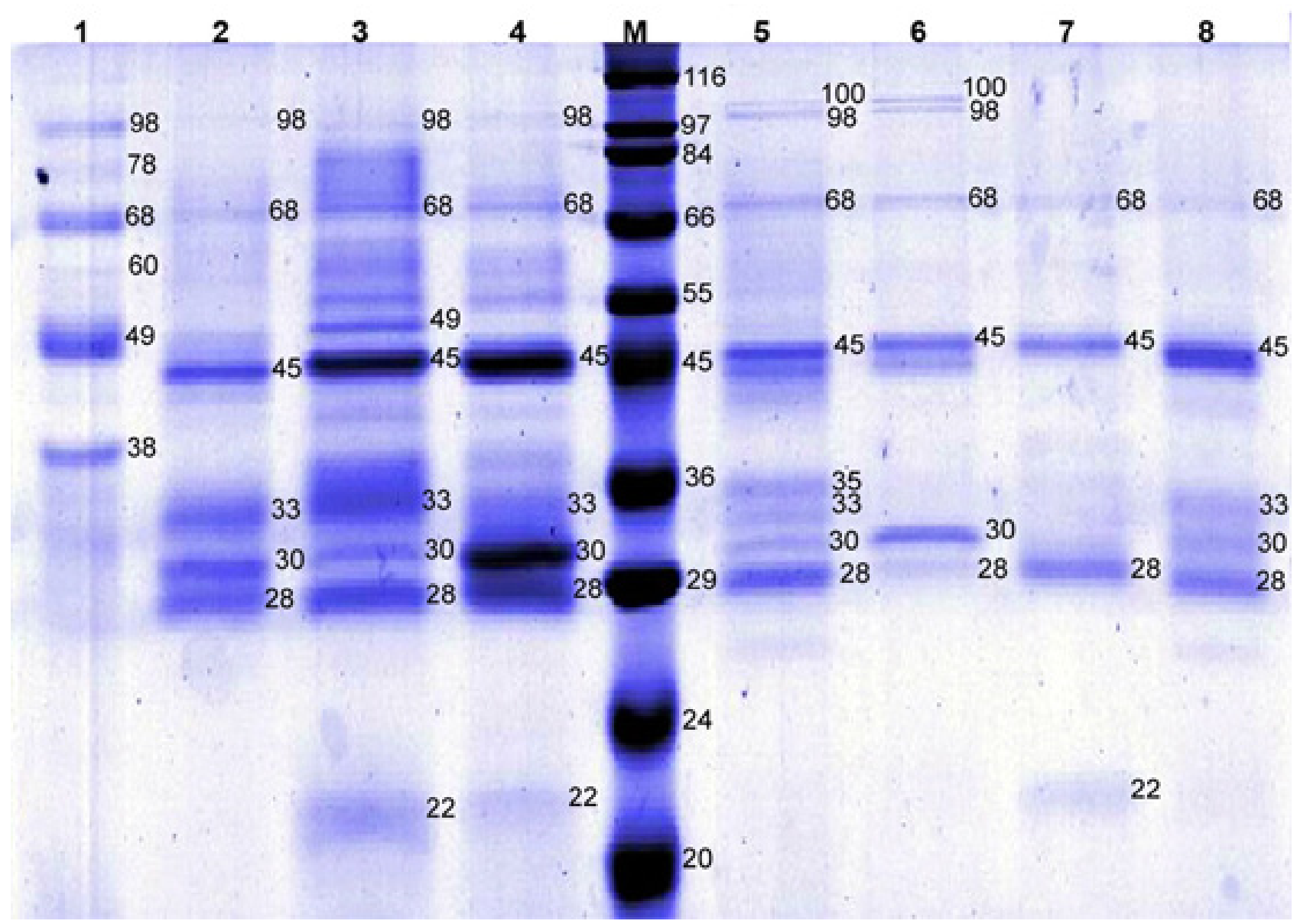

Figure 1. The proteins of Mesobuthus gibbosus venom were separated by SDS-PAGE (10\% polyacrylamide gel). Molecular mass markers (M); $116 \mathrm{kDa}$ - $\beta$-galactosidase, $97 \mathrm{kDa}$ - phosphorylase $\mathrm{B}, 66 \mathrm{kDa}$ - albumin, $45 \mathrm{kDa}$ - ovalbumin and $20 \mathrm{kDa}$-trypsin inhibitor.

male scorpions were employed to standardize the venom samples. Following a short acclimation period of two days in the laboratory, venom was extracted by electrical stimulation of the telson.

SDS-PAGE showed considerable variation of protein bands among the scorpion venoms (Figure 1). A total of 50 protein bands were detected in the venom samples altogether.

Analysis of individual venom samples showed that two protein bands with molecular masses of 30 and 98 $\mathrm{kDa}$ were found in six venom samples and were absent in the other venoms. Two different protein bands with molecular masses of 28 and $45 \mathrm{kDa}$ were detected in seven of the venom samples. Only one protein band with molecular mass of $68 \mathrm{kDa}$ was detected in all of the venom samples. In addition, three protein bands $(38,60,78 \mathrm{kDa})$ were determined in only one scorpion venom, and only one protein band $(35 \mathrm{kDa})$ was detected in one scorpion venom (Table 1).

Calvete et al. (10) suggest that inter- and intraspecies heterogeneity in venom composition may account for differences in clinical symptoms observed in human victims of envenoming by the same snake species in different geographic regions. The scorpion venom can cause a variety of symptoms, from pain at the sting site to death. The individual variability of venom in the same species must be taken into account to understand the clinical symptoms (3). Analysis of the literature shows that the main clinical features of M. gibbosus scorpion envenomation are systemic manifestations and death $(8,11-14)$.

Ucar and Tas (15) showed that the crude venom of M. gibbosus from Manisa province consisted of 19 protein bands with molecular masses ranging between 6.5 and $210 \mathrm{kDa}$ by SDS-PAGE analysis. Differences have also been described for the venoms of Mesobuthus tamulus (4), Androctonus mauretanicus (5), Androctonus australis hector (16), Iurus dufoureius asiaticus (17), Scorpio maurus palmatus (18), Tityus serrulatus (19), and Leiurus quinquestriatus (20). Thus, the individual 
Table 1. Individual variations determined by SDS-PAGE analysis in the protein profile of Mesobuthus gibbosus scorpion venom samples collected from the Mugla province

\begin{tabular}{|c|c|c|c|c|c|c|c|c|c|}
\hline \multirow{2}{*}{ Protein bands $(\mathrm{kDa})$} & \multicolumn{8}{|c|}{ Scorpion venom samples } & \multirow{2}{*}{ Number of protein bands } \\
\hline & 1 & 2 & 3 & 4 & 5 & 6 & 7 & 8 & \\
\hline 100 & & & & & + & + & & & 2 \\
\hline 98 & + & + & + & + & + & + & & & 6 \\
\hline 78 & + & & & & & & & & 1 \\
\hline 68 & + & + & + & + & + & + & + & + & 8 \\
\hline 60 & + & & & & & & & & 1 \\
\hline 49 & + & & + & & & & & & 2 \\
\hline 45 & & + & + & + & + & + & + & + & 7 \\
\hline 38 & + & & & & & & & & 1 \\
\hline 35 & & & & & + & & & & 1 \\
\hline 33 & & + & + & + & + & & & + & 5 \\
\hline 30 & & + & + & + & + & + & & + & 6 \\
\hline 28 & & + & + & + & + & + & + & + & 7 \\
\hline 22 & & & + & + & & & + & & 3 \\
\hline $\begin{array}{c}\text { Total number of protein } \\
\text { bands }\end{array}$ & 6 & 6 & 8 & 7 & 8 & 6 & 4 & 5 & 50 \\
\hline
\end{tabular}

variability in venoms is extremely important for evaluating the venom yield and the resulting toxicity after a scorpion sting (3). The present study reports the individual variability in $M$. gibbosus venom assessed by SDS-PAGE.

Variations in venom of individual animals could be explained by two different reasons, according to Abdel-Rahman et al. (18). Firstly, due to variations in the geographic and/or sexual status of the animals and secondly, due to differences in their individual markers, which elicit variability within the same specimen that could be related to temporary influences such as age, seasonal changes, feeding behavior or dynamics in gland production and peptide maturation $(18,21)$. One of the factors that may influence venom toxicity and cause variable results is the environmental condition. It is possible that geographic variation in venom composition reflects natural selection for feeding on local prey (22). In the current work, the factors that influence venom composition such as age (as indicated by the scorpion size), phenotype, diet, gender, geography and collecting time were all standardized. Analysis of individual venom samples showed that two protein bands (30 and $98 \mathrm{kDa}$ ) were common in six venom samples and could not be detected in other venoms. Two different protein bands with molecular masses of 28 and $45 \mathrm{kDa}$ were detected in seven venom samples. Only one protein band with molecular mass of 68
$\mathrm{kDa}$ was detected in all the samples. These findings corroborate those by Abdel-Rahman et al. (18), who indicated that such differences in venom composition may be a result of genetic factors as well as venom regeneration status.

A critical step in the preparation of antivenoms is the selection of venoms to be used in the immunizing mixture (22). The results of the current work show that the individual variation in scorpion venoms is an important point to take into account in producing an effective antivenom. Therefore, mixtures of numerous venom extractions from different specimens of the same scorpion species must be pooled and used in the preparation of antivenoms. M. gibbosus is responsible for a large number of scorpion stings due to its wide geographic distribution in Turkey. Therefore, venom of this scorpion must be studied first and in accordance with its geographical origin, age, and feeding state.

Finally, it is necessary to identify toxic and immunogenic proteins of $M$. gibbosus venom. Clearer identification of immunogenic proteins in this venom may contribute to the development of more efficient antivenoms.

\section{ACKNOWLEDGMENTS}

We wish to thank Juliana Simionato for her valuable comments and high-quality editing on this manuscript. 


\section{COPYRIGHT}

\section{(C) CEVAP 2010}

\section{SUBMISSION STATUS}

Received: March 16, 2010.

Accepted: June 11, 2010.

Abstract published online: June 21, 2010.

Full paper published online: August 31, 2010.

\section{CONFLICTS OF INTEREST}

There is no conflict.

\section{CORRESPONDENCE TO}

OZCAN OZKAN, Refik Saydam Public Health Agency, 06100 Ankara, Turkey. Phone: $00+90312$ 49821 50. Email: ozcanozkan_62@hotmail.com.

\section{REFERENCES}

1. Chippaux JP, Goyffon M. Epidemiology of scorpionism: a global appraisal. Acta Tropica. 2008;107(2):71-9.

2. World Health Organization. Who Expert Committee on Biological Standardization. Twenty-first report. Geneva: WHO; 1969. WHO Technical Report Series, No. 413. Available from: http:// whqlibdoc.who.int/trs/WHO_TRS_413.pdf.

3. El-Hafny B, Chgoury F, Adil N, Cohen N, Hassar $\mathrm{M}$. Intraspecific variability and pharmacokinetic characteristics of Androctonus mauretanicus scorpion venom. Toxicon. 2002;40(11):1609-16.

4. Badhe RV, Thomas AB, Harer SL, Deshpande AD, Salvi N, Waghmare A. Intraspecific variation in protein of red scorpion (Mesobuthus tamulus, Coconsis, Pocock) venoms from Western and Southern India. J Venom Anim Toxins incl Trop Dis. 2006;12(4):612-9.

5. Kalapothakis E, Chavez-Olortegui C. Venom variability among several Tityus serrulatus specimens. Toxicon. 1997;35(10):1523-9.

6. Ozkan O, Adıguzel S, Yakıstıran S, Filazi A. Study of the relationship between Androctonus crassicauda (Olivier, 1807; Scorpiones, Buthidae) venom toxicity and telson size, weight and storing condition. J Venom Anim Toxins incl Trop Dis. 2006;12(2):297-309.

7. Ozkan O, Uzun R, Adıguzel S, Cesaretli Y, Ertek M. Evaluation of scorpion sting incidence in Turkey. J Venom Anim Toxins incl Trop Dis. 2008;14(1):128-140.

8. Suzek H, Evren H, Yapar S. Mugla Devlet hastanesi acil servisine bașvuran akrep ve yllan sokma vakalarının incelenmesi. Uluslararası İnsan Bilimleri Dergisi . 2004;1(1):1-4.

9. Laemmli K. Cleavage of structural proteins during the assembly of the head of bacteriophage T4. Nature. 1970;227(5259):680-5.

10. Calvete JJ, Sanz L, Angulo Y, Lomonte B, Gutiérrez JM. Venoms, venomics, antivenomics. FEBS Letters. 2009;583(11):1736-43.

11. Canpolat M, Per H, Gümüş H, Narin N, Kumandaş S. Convulsions as a rare complication of scorpion bite. Erciyes Týp Dergisi. 2008; 30(3):175-9.

12. Karakurt C, Kocak G. Toxic myocarditis after scorpion envenomation: case report. İnönü Üniversitesi Tip Fakültesi Dergisi. 2007;14(1):613.

13. Pirgon O, Sert A, Atabek ME, Tokgöz H. The follow-up by cardiac troponin I of cardiac involvement in a case with scorpion envenoming. Selçuk Tip Derg. 2005;21(3):88-90.

14. Altınkaynak S, Ertekin V, Alp H. Scorpion envenomation in children. Turk Arch Ped. 2002;37(1):48-54.

15. Ucar G, Tas C. Cholinesterase inhibitory activities of the scorpion Mesobuthus gibbosus (Buthidae). FABAD J Pharm Sci. 2003;28(1):61-70.

16. El Ayeb $M$, Rochat $H$. Polymorphism and quantitative variations of toxins in the venom of the scorpion Androctonus australis hector. Toxicon. 1985;23(5):755-60.

17. Keskin NA, Koc H. A study on venom proteins of Iurus dufoureius asiaticus Birula, 1903 (Scorpiones: Iuridae). Türkiye Parazitoloji Dergisi. 2006;30(1):59-61.

18. Abdel-Rahman MA, Omran MAA, Abdel-Nabi IM, Ueda $\mathrm{H}, \mathrm{McVean} \mathrm{A}$. Intraspecific variation in the Egyptian scorpion Scorpio maurus palmatus venom collected from different biotopes. Toxicon. 2009;53(3):349-59.

19. Pimenta AM, De Marco Almeida F, de Lima ME, Martin-Eauclaire ME, Bougis PE. Individual variability in Tityus serrulatus (Scorpiones, Buthidae) venom elicited by matrix-assisted laser desorption/ionization time-of-flight mass spectrometry. Rapid Commun Mass Spectrom. 2003;17(5):413-8.

20. Omran MA, McVean A. Intraspecific variation in scorpion Leiurus quinquestriatus venom collected from Egypt (Sinai and Aswan deserts). J Toxicol Toxin Rev. 2000;19(3-4):247-64.

21. Calvete JJ. Antivenomics and venom phenotyping: a marriage of conveniencetoaddress theperformance and range of clinical use of antivenoms. Toxicon. Article in press. doi:10.1016/j.toxicon.2009.12.015.

22. Aguilar I, Guerrero B, Maria Salazar A, Giron ME, Perez JC, Sanchez EE, et al. Individual venom variability in the South American rattlesnake Crotalus durissus cumanensis. Toxicon. 2007;50(2):214-24. 